\title{
Growth ring width of Pinus Caribaea and its relationship with wood properties
}

\author{
Relação da largura dos anéis de crescimento da madeira de Pinus \\ Caribaea com suas propriedades
}

\author{
Joaquim Carlos Gonçalez ${ }^{1}$, Nayara Santos ${ }^{1}$, Francides Gomes da Silva Junior ${ }^{2}$, \\ Roberta Santos Souza ${ }^{2}$ e Marcella Hermida de Paula ${ }^{1}$
}

\begin{abstract}
A striking feature of the genus Pinus are its growth rings, which originate from the seasonal activity of vascular change resulting in successive depositions on the stem. The technological properties of Pinus wood present variations related to the width of the growth rings, which is a conditioning factor in the physical-mechanical wood performance. The wood of Pinus caribaea used in this research came from a 20 year old plantation in the region of Catalão - GO. Thirty-five specimens divided into three groups according to the width of the growth rings were analyzed: Group 1 (0.0 to $0.7 \mathrm{~cm}$ - higher percentage of late wood, fine and narrow rings); Group 2 ( 0.7 to $1.2 \mathrm{~cm}$ - the percentage of early and late wood is similar - rings of medium width); Group 3 (1.2 to $2.0 \mathrm{~cm}$ - higher percentage of early wood). The basic density, shrinking ability, modulus of elasticity and modulus of rupture were analyzed in static flexion tests, and dynamic elastic moduli determined by stress wave and ultrasound methods. The results indicate that Pinus caribaea wood with narrower growth rings (greater percentage of late wood, corresponding to group 1) have higher values of density, shrinking ability and also higher stiffness. In this group, the correlations between the properties are higher. In general, the modulus of dynamic elasticity determined by stress wave showed a better correlation with the studied properties than that determined by ultrasound.
\end{abstract}

Keywords: Pinus caribea, growth rings, properties, correlation

\section{Resumo}

Uma das características marcantes do gênero Pinus são seus anéis de crescimento, que tem como origem, a atividade sazonal do cambio vascular resultando em sucessivas deposições de lenho no fuste. As propriedades tecnológicas da madeira de Pinus apresentam variações em função da largura dos anéis de crescimento, o que acaba sendo fator condicionante no desempenho físico-mecânico da madeira. A madeira de Pinus caribaea utilizada nesta pesquisa é proveniente de um plantio de 20 anos da região de Catalão - GO. Foram analisados 45 corpos de prova divididos em 3 grupos de acordo com a largura dos anéis de crescimento: Grupo 1 ( 0,0 a 0,7 cm - maior percentagem de lenho final. Anéis finos e estreitos); grupo 2 ( 0,7 a $1,2 \mathrm{~cm}$ - o percentual de lenho inicial e final é próximo. Anéis de largura mediana); grupo 3 (1,2 a 2,0 cm - maior percentagem de lenho inicial. Anéis largos). Analisou-se a densidade básica, retratibilidades, modulo de elasticidade e modulo de ruptura em ensaios de flexão estática e módulos de elasticidades dinâmicos, determinados por métodos de stress wave e ultrassom. Os resultados obtidos indicam que a madeira de Pinus caribaea com anéis de crescimento mais estreitos (maior percentual de lenho final, correspondente ao grupo 1), possuem maiores valores de densidade, retratibilidade e também maior rigidez. Também para este grupo, as correlações entre as propriedades são mais elevadas. De uma forma geral, o modulo de elasticidade dinâmico determinado por stress wave mostrou melhor correlação com as propriedades estudadas que o determinado por ultrassom.

Palavras-chave: Pinus caribea, anéis de crescimento, propriedades, correlação.

\section{INTRODUCTION}

Pinus caribea and its better known varieties caribaea, bahamensis and hondurensis, have a high potential for plantation forests in the tropics. They originate from Central America, and in Brazil plantations are to be found mainly in the states of Paraná (42\%), Santa Catarina (34\%), Minas

1. Forestry Engineering Department, Universidade de Brasília, UnB. Brasília / DF, Brazil. E-mail: marcellahermida@ hotmail.com

2. Escola Superior de Agricultura "Luiz de Queiroz" - ESALQ, Universidade de São Paulo, USP.

Sci. For., Piracicaba, v. 46, n. 120, p. 670-678, dez. 2018 DOI: dx.doi.org/10.18671/scifor.v46n120.15 
Gerais, São Paulo, Bahia, Goiás and some states in the North and Northeast, with 1.6 milions hectare planted (IBÁ, 2017).

Pine wood has as one of its main characteristics the presence of visible growth rings. Growth rings originate from the seasonal activity of vascular cambium resulting in successive depositions of xylem on the stem (ESAU, 1974). The more evident the growth rings, the easier it is to define the beginning and end of the growth of a tree, in general corresponding to one year. According to the above author, each growth ring in conifers can be differentiated into two areas, one light, the other dark. In a growth ring the lighter wood, called early wood, is basically formed by cells with a larger lumen, thinner cell walls and consequently, less dense wood. The dark wood, called late wood, is made up of cells with thicker cell walls, resulting in denser wood (KOLLMAN; CÔTÉ, 1968).

One way to study some of the characteristics which affect the growth of the trees is by studying its growth rings. The variability of the growth rings influences the physical chemical characteristics, which for the use of wood may mean different uses of the final product. Thus it is important to know the variability of the growth rings (RALL, 2006). It is of high importance to recall the presence of early and late wood which compose the growth ring, mainly in the first few years of age. According to Correa (2007), studies in Pinus caribaea var. hondurensis show that juvenile wood is quickly formed in planted trees, notably in fertile environments, because of the more vigorous growth of this variety when compared to the others, coming to commercial dimension with a high proportion of juvenile wood, with a higher proportion of early wood than late wood, presenting shorter thacheids and wood with low resistance. Juvenile wood, in general, is characterized by a lower density, a higher angle of microfibrils in the S2 layer, shorter tracheids, smaller transversal contraction, higher longitudinal contraction, a higher proportion of reaction wood, smaller proportion of late wood, thinner cell walls, a higher content of lignin and hemicellulose, a smaller amount of cellulose and lower resistance when compared to adult wood (BENDTSEN, 1978; BENDTSEN; SENFT, 1986; ROWELL et al., 2000; ZOBEL; BUIJTENEN 1989). Thus, the variations between the wood properties of juvenile and adult wood can interfere negatively in the industrialization process and the transformation of wood into products. Growth ring width has a large influence in the technological properties of wood, varying from a fraction of millimetres to a few centimetres, depending on the duration of the vegetative period, temperature, humidity, luminosity and silvicultural management. In some conifers, the width of the rings ends up being a conditioning factor for the physical mechanical performance of the wood. According to Panshin and Zeeuw (1980), the wider the growth rings, the lower its mechanical resistance. Wood with a higher proproportion of early wood will tend to show lower density and lower mechanical resistance. The study of the relationship between density and growth ring width is controversial. Much literature states a negative relationship, while others present quite different results: positive correlations (MATTOS et al., 2006; ROLIM; FERREIRA, 1974) or no correlations (ALVARADO et al., 2010). One of the possible causes for this result disparity could be due to the fact that many of these studies were done based on incorrect sampling, age effect, site effects and others. Rosa et al. 2013, when studying Araucaria wood found that wider growth rings ( $>5 \mathrm{~mm}$ ) showed lower values of volume contraction than rings $<5 \mathrm{~mm}$ wide. Melo et al. (2010) found that Araucaria wood obtained near the bark (adult wood) was more stable than wood from close to the pith (juveniel wood). Classification criteria based on the number of growth rings and late wood can also provide subsidies for wood selection. Haselein et al. (2000), when working with Pinus elliottii, concluded that wood properties near the bark were significantly superior than in wood formed near the pith in trees less than 30 years old. They inform that the norm Southern Pine Inspection Bureau (SPIB), from 1994, suggests that denser pine wood is the one having at least six growth rings per inch measured on a radial line and at least $1 / 3$ of late wood or four growth rings per inch and with at least $50 \%$ late wood. The objective of this work was to verify the influence of growth ring width of Pinus caribaea wood on its technological properties (density, retractability and static flexion). Dynamic elasticity modules were also determined through ultrasound and stress wave.

\section{MATERIALS AND METHODS}

This research was developed in the Forestry Department of the University of Brasilia. Ten wooden boards were collected ( $250 \times 20 \times 4.0 \mathrm{~cm}$, respectively, length, width and thickness) of Pinus caribaea in an industry of the Federal District. This wood comes from a 20 year old plantation from the region of 
Catalão GO - Brazil. From these boards samples measuring 2 × 2 × $10 \mathrm{~cm}$ and $2 \times 2 \times 30 \mathrm{~cm}$ were made. The samples were divided into three groups: 15 samples with narrow growth rings (from 0 to $0.7 \mathrm{~cm}$ ); 15 samples with intermediate growth rings (from 0.7 to $1.2 \mathrm{~cm}$ ) and 15 samples with larger growth rings (from 1.2 to $2 \mathrm{~cm}$ ), as seen in figure 1 and table 1 .

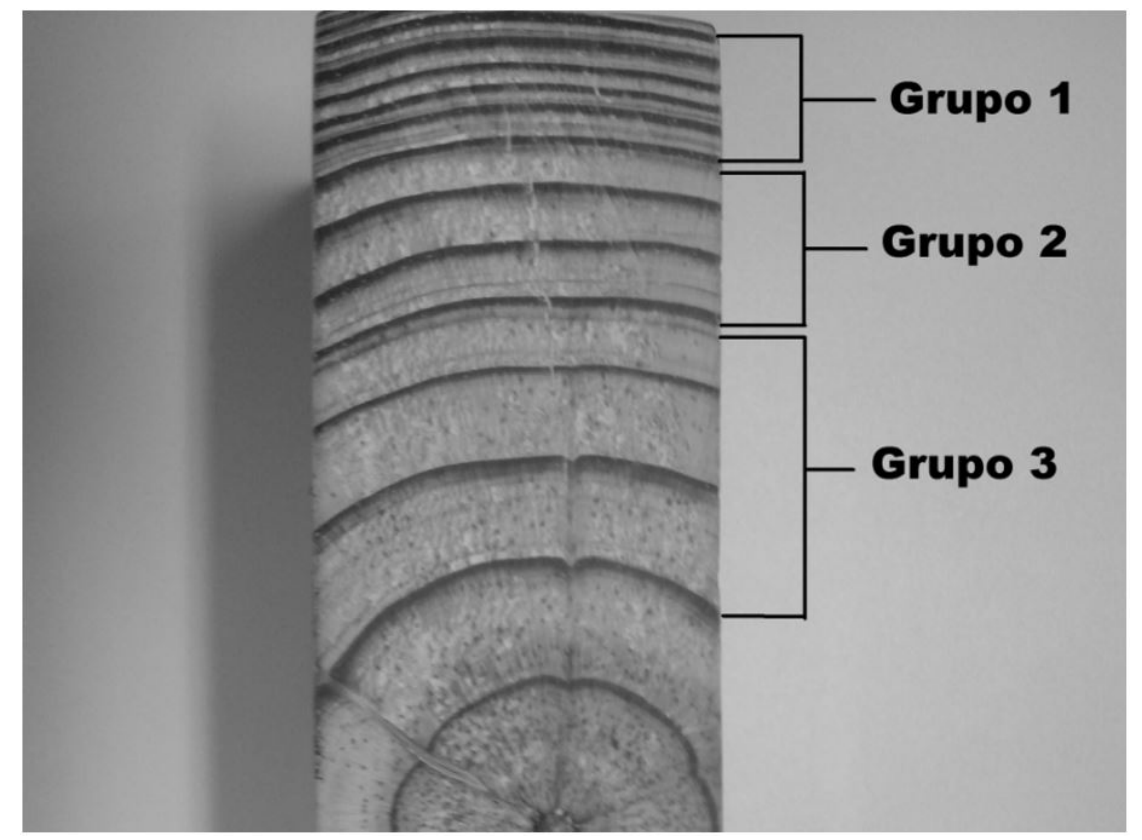

Figure 1. Sampling groups on a Pinus caribea board with intervals of growth ring widths Figura 1: Grupos de amostragem com intervalos de larguras do anel de crescimento

Table 1. Sampling Groups with intervals of growth ring widths

Tabela 1. Grupos amostrais com intervalos de largura dos anéis de crescimento

\begin{tabular}{ccl}
\hline Groups & Intervals & Growth ring composition \\
\hline Group 1 & $0.0-0.7 \mathrm{~cm}$ & Higher percentage of late wood. Fine and narrow rings. \\
Group 2 & $0.7-1.2 \mathrm{~cm}$ & Percentage of early and late wood is similar. Rings of medium width. \\
Group 3 & $1.2-2 \mathrm{~cm}$ & Higher percentage of early wood. Wide rings. \\
\hline
\end{tabular}

For the physical properties (wood density and volumetric, tangential and radial retractabilities) samples of $2 \times 2 \times 10 \mathrm{~cm}$ were used. For the elasticity module (MOE) and rupture module (MOR) samples of $2 \times 2 \times 30 \mathrm{~cm}$ were used. Both physical and mechanical properties were done according to the norms of the Pan American Commission of Technical Norms (COPANT, 2016): COPANT (461/1972 - density and 462/1972 - retractability) and COPANT 555/1973 - static flexion. Ultrasound and stress wave tests were done on the $2 \times 2 \times 30 \mathrm{~cm}$ samples, preceding the static flexing test, according to Del Menezzi (2010).

- Wood density: The $2 \mathrm{~cm} \times 2 \mathrm{~cm}$ x $10 \mathrm{~cm}$ samples were saturated in water to determine saturated volume. With a digital scale of $0.01 \mathrm{~g}$ precision and a beaker with water it was possible to obtain the saturated volume by the Archimedes principle. Then the samples were taken to the oven at a temperature of $103 \pm 2{ }^{\circ} \mathrm{C}$ until they attained a constant mass, for the determination of dry mass;

- Retractability: Was done through measurements in the tangential, radial and volumetric directions on the samples, by using a digital pachymeter with a precision of $.01 \mathrm{~mm}$, under totally saturated and totally kiln dried conditions;

- Static flexion: The samples were climatized for about sixty days to obtain a mean humidity of $12 \%$. Then a universal sample machine model EMIC DL $30 \mathrm{kN}$ was used to determine MOE (Elasticity module) and MOR (Rupture module);

- Dynamic Elasticity Module (MOEd) was determined by the usage of two methods: ultrasound (MOEdu) and stress wave (MOEds);

- Ultrasound: The equipment used was Ultrasound USlab Agricef at a frequency of $45 \mathrm{kH}$. With the values of propagation time and the distance traveled, the speeds of propagation for each sample were calculated after the MOEdu, according to Equation 1; 
- Stress wave: The equipment used was the Stress Wave Timer Metriguard 239A. Samples were placed between two accelerometres, one on each end of the samples. The first sensor was placed on the side of the impact which generated the tension wave and the second on the opposite side. Thus the time of propagation starts to be counted when the tension wave starts at the starting accelerometer and ends when it reaches the ending accelerometer. MOEds were calculated according to Equation 1.

$$
\text { MOEdu or MOEds }=V^{2} . D 12 \% .1 / \mathrm{g}
$$

(Equation 1)

Where:

MOEdu = Dynamic elasticity module using ultrassound (MPa);

MOEds = Dynamic elasticity module using stress wave $(\mathrm{MPa})$;

$\mathrm{V}=$ wave propagation speed $(\mathrm{m} / \mathrm{s})$;

$\mathrm{D} 12 \%$ = density at $12 \%$ humidity $\left(\mathrm{g} / \mathrm{cm}^{3}\right)$;

$\mathrm{g}=$ gravity acceleration $\left(9,804 \mathrm{~m} / \mathrm{s}^{2}\right)$.

Aside from descriptive statistics, for physical and mechanical properties we performed an analysis of variance (ANOVA) between sample groups. The Tukey test was used for comparing means at the level of 95\% probability. Correlation was also used to evaluate the correspondence between variables. The statistical program R (version 3.2.2) was used for data analysis.

\section{RESULTS AND DISCUSSION}

Table 2 shows the mean basic density values and retractabilities (tangential, radial and volumetric) for every sample group studied, with a statistical comparison of these properties.

When analyzing Table 2, one sees that basic density presented significant differences in the three studied groups, where the highest density mean is that of group 1 (narrower growth rings, more late wood). Group 3 had the smallest density (wider rings, higher percentage of early wood). Retractabilities followed the same tendency as density, or be it, group 1 had the highest retractabilities. There were no significant differences between retractabilities of groups 1 and 2 . There were also no significant statistical differences between groups 2 and 3. This shows that the intermediate group (group 2) had the influence of early and late wood with more participation in one or the other group.

For group 1 the major influence was that of late wood and for group 3 the major influence was that of early wood. The biggest retractabiities in group 1 were to be expected, as denser woods have a higher amount of matter (fibers), with a higher probability of the wood to "work", leading to higher retractabilities. On the other hand, wider growth rings (group 3 - higher percentage of early wood), more distant from the bark, in the radial sense of the stem, are the ones which normally also present a higher amount of early wood, helping to understand the lower density and retractabilities of this group. According to Panshin and Zeeuw (1980), growth rings next to the pith are wider with shorter tracheids and lower density and resistance. Rall (2006) also mentions that for the exotic Pinus planted in Brazil, growth rings of juvenile wood are wider (due to the large proportion of early wood, with less late wood, which is denser).

We studied the correlations between physical properties in each group studied (Table 3).

Correlations between basic density and retractibilities (volumetric, tangential and radial) were generally low for the three groups. According to Tsoumis (1991), wood retractability is proportional to the amounts of extractives present in the wood. It is known that Pinus sp wood has a large amount of resins and this may have influenced the low correlation between these variables. The best correlations wer for groups 1 and 2 between basic density and radial retractibility. Volumetric retractability, as

Table 2. Mean values for basic density ( $D b)$, tangential retractibility (Rtg), radial (Rrd) and volumetric (Rv) in the sample groups studied.

Tabela 2. Valores médios para densidade básica (Db), retratibilidades tangencial (Rtg), radial (Rrd) e volumétrica (Rv) entre os grupos amostrais estudados.

\begin{tabular}{cclll}
\hline Groups & $\mathbf{D b}\left(\mathbf{g} / \mathbf{c m}^{3}\right)$ & $\operatorname{Rtg}(\%)$ & $\operatorname{Rrd}(\%)$ & $\operatorname{Rv}(\%)$ \\
\hline 1 & $0.51 \mathrm{a}$ & $7.96 \mathrm{a}$ & $6.53 \mathrm{a}$ & $14.14 \mathrm{a}$ \\
2 & $0.46 \mathrm{~b}$ & $6.57 \mathrm{ab}$ & $5.52 \mathrm{ab}$ & $11.91 \mathrm{ab}$ \\
3 & $0.41 \mathrm{c}$ & $6.00 \mathrm{~b}$ & $4.92 \mathrm{~b}$ & $10.86 \mathrm{~b}$ \\
\hline
\end{tabular}

Sample groups: Group I: samples with growth ring widths between 0 and $0.7 \mathrm{~cm}$; Group 2: samples with growth ring widths between 0.7 and I. $2 \mathrm{~cm}$ and Group 3: samples with growth ring widths between 1.2 and $2 \mathrm{~cm}$. Means followed by different letters in the same column were statistically different by the Tukey test at the $5 \%$ significance level. 
Gonçalez et al. - Growth ring width of Pinus Caribaea and its relationship

with wood properties

Table 3. Correlation of basic density ( $\mathrm{Db})$, tangential (Rtg), radial (Rrd) and volumetric retractabilities (Rv) in the three studied groups.

Tabela 3. Correlação da densidade básica (Db), retatibilidades tangencial (Rtg), radial (Rrd) e volumétrica(Rv) para os três grupos estudados.

\begin{tabular}{|c|c|c|c|c|}
\hline \multicolumn{5}{|c|}{ Group 1} \\
\hline & $\mathrm{Db}$ & Rtg & Rrd & Rv \\
\hline $\mathrm{DB}$ & 1 & & & \\
\hline Rtg & 0.206 & 1 & & \\
\hline Rrd & 0.418 & 0.215 & 1 & \\
\hline $\mathrm{Rv}$ & 0.260 & 0.688 & 0.847 & 1 \\
\hline \multicolumn{5}{|c|}{ Group 2} \\
\hline & $\mathrm{Db}$ & Rtg & Rrd & Rv \\
\hline DB & 1 & & & \\
\hline Rtg & 0.191 & 1 & & \\
\hline Rrd & 0.542 & 0.497 & 1 & \\
\hline $\mathrm{Rv}$ & 0.416 & 0.907 & 0.802 & 1 \\
\hline \multicolumn{5}{|c|}{ Group 3} \\
\hline & $\mathrm{Db}$ & Rtg & Rrd & Rv \\
\hline DB & 1 & & & \\
\hline Rtg & 0.241 & 1 & & \\
\hline Rrd & 0.003 & 0.488 & 1 & \\
\hline $\mathrm{Rv}$ & 0.162 & 0.887 & 0.825 & 1 \\
\hline
\end{tabular}

expected, had a good corrleation with radial and tangential retractibilities in the three groups. This was expected because volumetric retractability is the sum of the other two, aside from longitudinal retractability.

Table 4 shows the mean values of propagation speed and dynamic elasticity modules determined by stress wave and ultrasound for each sample group, and also the statistical comparison of these properties.

Table 4. Mean values of propagation speed (Vprop) and Dynamic elasticity Module (MOEds and MOEdu) for stress wave and ultrasound among the three studied groups.

Tabela 4. Valores médios para velocidade de propagação (Vprop) e Modulo de elasticidade dinâmico (MOEds e MOEdu) para stress wave e ultrassom entre os três grupos estudados.

\begin{tabular}{cccccc}
\hline \multirow{2}{*}{ Groups } & \multicolumn{2}{c}{ Stress wave } & & \multicolumn{2}{c}{ Ultrasound } \\
\cline { 2 - 3 } \cline { 5 - 6 } & Vprop $(\mathbf{m} / \mathbf{s})$ & MOEds $(\mathbf{M P a})$ & & Vprop (m/s) & MOEdu (MPa) \\
\hline 1 & $5167.45 \mathrm{a}$ & $17,670 \mathrm{a}$ & & $5852.85 \mathrm{a}$ & $22,600 \mathrm{a}$ \\
2 & $4624.97 \mathrm{~b}$ & $12,560 \mathrm{~b}$ & & $5262.22 \mathrm{~b}$ & $16,280 \mathrm{~b}$ \\
3 & $4316.80 \mathrm{c}$ & $10,370 \mathrm{c}$ & & $4848.30 \mathrm{c}$ & $13,180 \mathrm{c}$ \\
\hline
\end{tabular}

Sample groups: Group I: samples with growth ring widths from 0 and $0.7 \mathrm{~cm}$; Group 2: samples with growth ring widths between 0.7 and I.2 cm, and Group 3: samples with growth ring widths between 1.2 and $2 \mathrm{~cm}$. Means followed by different letters in the same column have significant difference by the Tukey test at $5 \%$ significance level.

This table shows that speed propagation and dynamic elasticity module determined by stress wave and by ultrasound, present statistical differences between the three wooden samples studied. Group 1, the one with highest late wood proportion, therefore of highest density, was the one presenting the highest values for these two variables. Group 3, of highest early wood, had the lowest values for both variables. Group 2 had intermediate values between groups 1 and 3, indicating that the presence of both kinds of wood (early and late) in intermetiate proportions to the other two, also led to intermediate values both of wave propagation speed and dynamic elasticity module. This shows that a higher presence of late wood in the growth ring (group 1) favors the speed of movement of wave propagation, implying in higher dynamic elasticity modules. The presence of early wood however, less dense and possibly more porous, has an inverse effect, that is, diminishes propagation speed in the wood, leading to a smaller dynamic elasticity module.

According to Gonçalez et al. (2001), propagation speed (Vprop) of the wave is influenced by the amount of wooden material. Thus generally, the denser the wood, the higher its elasticity module, confirming the results of this work. 
Table 5 presents the mean static flexion values of rupture modules (MOR) and elasticity modules (MOE) for the three goups of Pinus caribaea wood, with a statistical comparison of these properties of the studied groups.

Table 5. Mean values in the static flexing tests (MOE e MOR) in the three wood groups studied.

Tabela 5. Valores médios dos ensaios em flexão estática (MOE e MOR) para os três grupos de madeiras estudados.

\begin{tabular}{ccc}
\hline Groups & MOE $(\mathbf{M P a})$ & MOR $(\mathrm{MPa})$ \\
\hline 1 & $11,568 \mathrm{a}$ & $93.49 \mathrm{a}$ \\
2 & $10,051 \mathrm{~b}$ & $101.68 \mathrm{a}$ \\
3 & $8,670 \mathrm{c}$ & $80.25 \mathrm{~b}$ \\
\hline
\end{tabular}

Sample groups: Group I: samples with growth ring widths from 0 and $0.7 \mathrm{~cm}$; Group 2: samples with growth ring widths between 0.7 and I.2 cm, and Group 3: samples with growth ring widths between 1.2 and $2 \mathrm{~cm}$. Means followed by different letters in the same column have significant difference by the Tukey test at $5 \%$ significance level.

In Table 5 it can be seen that the static elasticity module (MOE) from group 1 (higher amount of late wood) was statistically higher than that of groups 2 and 3. However, the static rupture module (MOR) had a higher mean value in group 2.. Still, there was no statistical difference with group 1 and both are statistically superior to group 3 . In general, the values found in this work for the two properties (MOE e MOR) are in agreement with the literature for tropical Pinus wood (BALLARIN et al. 2005; RALL, 2006; TARGA, 2005; TRIANOSKI et al. 2013). The higher proportion of early wood in group 3, implying in less dense wood, also showed less resistance of the wood in static flexion, both for MOE and MOR.

After that we determined the correlations between the properties of propagation speed (Vprop), dynamic elasticity module found by ultrasound (MOEdu) and by stress wave (MOEds), static elasticity module (MOE) and rupture module (MOR) within each studied group (Tables 6 and 7).

Table 6. Correlation between the properties determined by non-destructive methods (stress wave) and destructive ones in static flexing (MOR and MOR) among the sample groups studied.

Tabela 6. Correlação entre propriedades determinadas por ensaios não destrutivos (stress wave) e destrutivos em flexão estática (MOR e MOR) dentro dos grupos amostrais estudados.

\begin{tabular}{|c|c|c|c|c|}
\hline \multicolumn{5}{|c|}{ Group 1} \\
\hline & Vprop & MOEds & MOE & MOR \\
\hline Vprop & 1 & & & \\
\hline MOEds & 0.867 & 1 & & \\
\hline MOE & 0.532 & 0.593 & 1 & \\
\hline MOR & 0.705 & 0.614 & 0.666 & 1 \\
\hline \multicolumn{5}{|c|}{ Group 2} \\
\hline & Vprop & MOEds & MOE & MOR \\
\hline Vprop & 1 & & & \\
\hline MOEds & 0.354 & 1 & & \\
\hline MOE & 0.189 & 0.538 & 1 & \\
\hline MOR & 0.133 & 0.044 & -0.257 & 1 \\
\hline \multicolumn{5}{|c|}{ Group 3} \\
\hline & Vprop & MOEds & MOE & MOR \\
\hline Vprop & 1 & & & \\
\hline MOEds & 0.526 & 1 & & \\
\hline MOE & 0.392 & 0.591 & 1 & \\
\hline MOR & 0.293 & 0.417 & 0.926 & 1 \\
\hline
\end{tabular}

Sample groups: Group I: samples with growth ring widths from 0 and $0.7 \mathrm{~cm}$; Group 2: samples with growth ring widths between 0.7 and I.2 cm, and Group 3: samples with growth ring widths between 1.2 and $2 \mathrm{~cm}$.

Table 6 shows that group 1 had the best correlations between the studied variables. Wave speed propagation in the wood had good correlations with MOEds, MOE and MOR. For this group the MOEds had also good correlations with MOE and MOR. For groups 2 and 3, MOE had good correlations with the MOEds. But MOR had a very good correlation with MOE in groups 1 and 3. Possibly the higher density in group 1 could be one of the reasons of the good correlations with the other studied properties. 
When checking Table 7, one finds that in group 1 there was the higherst correlation for the dynamic elasticity module (MOEdu) and propagation speed (Vprop). In group 2 the highest correlation was between flexion module of elasticity and dynamic elasticity module. In group 3 the highest correlation found was between rupture module and elasticity flexion module. This correlation is considered to be strong. However, we see that there is no correlation pattern between the variables within the groups and ultrasound.

Table 7. Correlation between the properties determined by non-destructive tests (ultrasound) and the destructive ones with static flexing (MOE e MOR) among the stuedied sample groups.

Tabela 7. Correlação entre propriedades determinadas por ensaios não destrutivos (ultrassom) e destrutivos em flexão estática (MOE e MOR) dentro dos grupos amostrais estudados.

\begin{tabular}{|c|c|c|c|c|}
\hline \multicolumn{5}{|c|}{ Group 1} \\
\hline & Vprop & MOEdu & MOE & MOR \\
\hline Vprop & 1 & & & \\
\hline MOEdu & 0.741 & 1 & & \\
\hline MOE & 0.584 & 0.573 & 1 & \\
\hline MOR & 0.707 & 0.501 & 0.666 & 1 \\
\hline \multicolumn{5}{|c|}{ Group 2} \\
\hline & Vprop & MOEdu & MOE & MOR \\
\hline Vprop & 1 & & & \\
\hline MOEdu & 0.443 & 1 & & \\
\hline MOE & 0.301 & 0.547 & 1 & \\
\hline MOR & 0.345 & 0.168 & -0.257 & 1 \\
\hline \multicolumn{5}{|c|}{ Group 3} \\
\hline & Vprop & MOEdu & MOE & MOR \\
\hline Vprop & 1 & & & \\
\hline MOEdu & 0.737 & 1 & & \\
\hline MOE & 0.583 & 0.622 & 1 & \\
\hline MOR & 0.434 & 0.442 & 0.926 & 1 \\
\hline
\end{tabular}

Sample groups: Group I: samples with growth ring widths from 0 and $0.7 \mathrm{~cm}$; Group 2: samples with growth ring widths between 0.7 and $1.2 \mathrm{~cm}$, and Group 3: samples with growth ring widths between 1.2 and $2 \mathrm{~cm}$.

\section{CONCLUSION}

Through this Pinus caribaea wood study we conclude that:

- Group 1, the wood with more late wood and narrow rings, was the one with highest basic density and tangential and radial retractibilities. Lowest density was found in group 3, which had a higher percentage of early wood and wider growth rings;

- In the three sampled groups, volumetric retractability showed a strong correlation with tangential and radial retractibilities;

- The dynamic elasticity module (both by stress wave and ultrasound) is higher in the woods with more late wood, or be it, in wood with narrower growth rings and higher density (group 1). Results obtained by non-destructive tests indicate that wood with narrower rings present higher rigidity;

- The best correlations of properties studied were presented by the wave propagation speed variable done by stress wave;

- In general, dynamic elasticity module determined by stress wave had a better correlation with the studied properties than those determined by ultrasound;

- Static elasticity module and rupture module determined through flexion are higher in woods with narrow growth rings (group 1);

- The likely presence of proportionally more juvenile wood in the sample group 3 is one of the main reasons for the lower values of density, retractabilities, dynamic elasticity modules and resistance in static flexion of this species.

\section{REFERENCES}

ALVARADO, J. R.; TOMAZELLO FILHO, M.; POLLITO, P. A. Z.; LOBÃO, M. S. Variação da densidade do lenho e relação com a largura dos anéis de crescimento de árvores de mogno, Swietenia macrophylla, da floresta tropical amazônica do Peru. Scientia Forestalis, Piracicaba, v. 38, n. 86, p. 171-179, 2010 
BALLARIN, A. W.; NOGUEIRA, M. Determinação do Módulo de Elasticidade da Madeira Juvenil e Adulta de Pinus taeda Por Ultra-som. Engenharia Agrícola, Jaboticabal, v. 25, n. 1, p.19-28, 2005.

BENDTSEN, B. A. Properties of wood from improved and intensively managed trees. Forest Products Journal, v. 28, n. 10, p. 61-72, 1978.

BENDTSEN, B.; SENFT, J. Mechanical and anatomical properties in individual growth rings of plantation-grown eastern Cottonwood and Loblolly Pine. Wood and Fiber Science, v. 18, n. 1, p. 21-38, 1986.

COPANT - COMISIÓN PANAMERICANA DE NORMAS TÉCNICAS. Catálogo de normas COPANT. Disponível em: < www.copant.org/web/guest/catalogo-de-normas-copant >. Acesso em: 08 ago. 2016.

CORREA, R. S. Efeito dos atributos do solo na produtividade e qualidade da madeira de Pinus caribaea var. hondurensis. Dissertação (Mestrado em Ciência do Solo) - Universidade Federal do Paraná, Curitiba, 2007.

DEL MENEZZI, C. H. S.; SILVEIRA, R. S.; SOUZA, M. R. Estimativa das propriedades de flexão estática de seis espécies de madeiras amazônicas por meio da técnica não-destrutiva de ondas de tensão. Acta Amazônica, Manaus, v. 40, n. 2, p. 325-332, 2010.

ESAU, K. Anatomia de plantas com sementes. São Paulo: Edgard Blücher, 1974.

GONÇALEZ, J.C.; VALLE, A.T.; COSTA, A.F. Estimativas das constantes elásticas da madeira por meio de ondas de ultra-sonoras (ultra-som). Cerne, Lavras, v. 7, n. 2, p. 81-92, 2001.

HASELEIN, C. R.; CECHIN. E.; SANTINI; E. J.; GATTO; D. A. Características estruturais da madeira de Pinus Elliottii Engelm aos 30 anos de idade. Ciência Florestal, Santa Maria, v. 10, n. 2, p.135-144. 2000.

IBÁ - INDÚSTRIA BRASILEIRA DE ÁRVORES. Relatório annual 2016. São Paulo: IBA, 2017.

KOllmaN, F. F.; A.CÔTÉ, W. Principles of Wood Science and Technology. New York: Springer-Verlag, 1969. p. 292-414.

MATTOS, P. P.; BORTOLI, C.; MARCHESAN, R.; ROSOT, N.C. Caracterização física, química e anatômica da madeira de Araucaria angustifolia(Bert.) O. Kuntze. Colombo: Embrapa Floresta, 2006. (Comunicado Técnico, $160)$.

MELO, R. R.; STANGERLIN, D. M.; DEL MENEZI, C. H. S.; GATTO, D. A.; CALEGARI, L.; Caracterização física e mecânica da madeira de Araucaria angustifolia (Bert.) O. Kuntze. Revista Brasileira de Ciências Agrárias, Recife, v. 5, n. 1, p. 67-73, 2010.

PANSHIN, A. J.; DE ZEEUW, C. de Textbook of wood technology. New York. Mc. Graw-hill. Company, 705 p. 1980 .

RALL, R. Influência das características dos anéis de crescimento na densidade, resistência e rigidez da madeira de Pinus taeda. Botucatu, Dissertação (Mestrado em Agronomia) - Universidade Estadual Paulista, SP, 2006.

ROLIM, M .B.; FERREIRA, M. Variação da densidade básica da madeira produzida Pela Araucaria angustifolia (bert.) O. Kuntze em função dos Anéis de crescimento. IPEF, Piracicaba, n. 9, p. 47 -55, 1974

ROSA T. S.; HILLIG E., VIANA L. C. Propriedades físicas da madeira de Araucaria angustifolia (bert.) o. kuntze e sua relação com os anéis de crescimento. Ciência da Madeira, Pelotas, v. 4, n. 1, p. 1-14, 2013.

ROWELL, R. M.; HAN, J. S.; ROWELL, J. S. Characterization and factors affecting fiber properties. In: NATURAL POLYMERS AND AGROFIBERS BASED COMPOSITES, 1., 2000, São Carlos. Anais... São Carlos: Embrapa Instrumentação Agropecuária, 2000. p.

TARGA, L. A.; BALLARIN, A. W.; BIAGGIONI, M. A. M. Avaliação do módulo de elasticidade da madeira com uso de método não-destrutivo de vibração transversal. Engenharia Agrícola, Jaboticabal, v. 25, n. 2 , 2005.

TSOUMIS, G. Science and technology of wood. Nova York: Chapman \& Hall, 1991. 494 p.

Sci. For., Piracicaba, v. 46, n. 120, p. 670-678, dez. 2018

DOI: dx.doi.org/10.18671/scifor.v46n120.15 
Gonçalez et al. - Growth ring width of Pinus Caribaea and its relationship

with wood properties

TRIANOSKI, R.; IWAKIRI, S.; MATOS, J. L. M. E; CHIES, D. Utilização da madeira de Cryptomeria japonica para produção de painéis aglomerados. Revista Scientia Forestalis, Piracicaba, v. 41, n. 97, p. 57-64, 2013

ZOBEL, B. J.; BUIJTENEN, J. P. Wood variation: its causes and control. Berlin: Springer-Verlag, 1989. 361p.

Recebido em: 13/07/2017

Aceito em: 26/03/2018 